\title{
Ezekiel 38-48
}

$$
\text { YALE }
$$

VOLUME 22 B 
THE ANCHOR YALE BIBLE is a project of international and interfaith scope in which Protestant, Catholic, and Jewish scholars from many countries contribute individual volumes. The project is not sponsored by any ecclesiastical organization and is not intended to reflect any particular theological doctrine.

THE ANCHOR YALE BIBLE is committed to producing commentaries in the tradition established half a century ago by the founders of the series, William Foxwell Albright and David Noel Freedman. It aims to present the best contemporary scholarship in a way that is accessible not only to scholars but also to the educated nonspecialist. Its approach is grounded in exact translation of the ancient languages and an appreciation of the historical and cultural contexts in which the biblical books were written, supplemented by insights from modern methods, such as sociological and literary criticism.

John J. Collins

General Editor 
THE ANCHOR YALE BIBLE

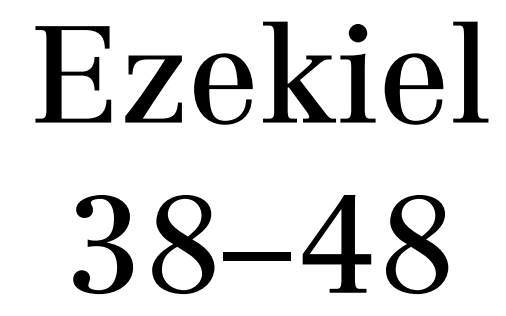

\author{
A New Translation with \\ Introduction and Commentary
}

\title{
STEPHEN L. COOK
}

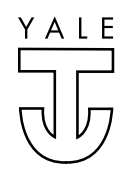

THE ANCHOR YALE BIBLE

Yale UnIVERSITY PRESS

New Haven \& London 
Published with assistance from the foundation established in memory of Philip Hamilton McMillan of the Class of 1894, Yale College.

"Anchor Yale Bible" and the Anchor Yale logo are registered trademarks of Yale University.

Copyright (C) 2018 by Yale University.

All rights reserved.

This book may not be reproduced, in whole or in part, including illustrations, in any form (beyond that copying permitted by Sections 107 and 108 of the U.S. Copyright Law and except by reviewers for the public press), without written permission from the publishers.

Yale University Press books may be purchased in quantity for educational, business, or promotional use. For information, please e-mail sales.press@yale.edu (U.S. office) or sales@yaleup.co.uk (U.K. office).

Set in Adobe Garamond type by Newgen North America.

Printed in the United States of America.

Library of Congress Control Number: 2018936849

ISBN 978-0-300-21881-7 (hardcover : alk. paper)

A catalogue record for this book is available from the British Library.

This paper meets the requirements of ANSI/NISO Z39.48-1992 (Permanence of Paper).

10987654321 